\title{
The Systems Approach in Developmental Psychology: Fundamental Concepts and Principles
}

\author{
Carolina Tinajero ${ }^{1}$ \\ M. Fernanda Páramo \\ Universidad de Santiago de Compostela
}

\begin{abstract}
Developmental Psychology seems to have come to an unifying theoretical framework which may make feasible to overcome the fragmentation so frequently referred to within the discipline. This is indicated by the widespread support being given to the systems approach, enriched by dialectic and contextual postulates. In this article, we briefly review the antecedents of this approach and explore its core concepts, indicating their roots and the precise way in which they are applied to developmental analyses today. We also examine the implications of the systems approach for developmental investigation, and its challenges.
\end{abstract}

Keywords: developmental psychology, contextualism, interactionism, systems view.

\section{Visão Sistêmica na Psicologia do Desenvolvimento: Conceitos e Princípios Fundamentais}

\begin{abstract}
RESUMO - A Psicologia do Desenvolvimento parece ter chegado a uma estrutura teórica de trabalho que pode tornar possível vencer a barreira da fragmentação, frequentemente referida na disciplina. Isto pode ser verificado pelo vasto suporte dado a visão dos sistemas, enriquecido pelos postulados contextuais e dialéticos. Neste artigo, nós brevemente revisamos os antecedentes dessa abordagem e exploramos seus conceitos básicos (centrais), indicando suas origens e caminhos precisos nos quais eles são aplicados na análise do desenvolvimento nos dias de hoje. Nós também examinamos as implicações da visão sistêmica para investigação do desenvolvimento e seus desafios.
\end{abstract}

Palavras-chave: psicologia do desenvolvimento, contextualismo, interacionismo e visão sistêmica.

Since its origins, Developmental Psychology has been characterized by the coexistence of theoretical perspectives, many of which are considered incompatible. This is the case with Piagetian and classical behavioral approaches, based respectively on organismic and mechanistic meta-theoretical assumptions (Overton \& Ennis, 2006).

Developmental psychologists frequently denounce the fragmentation of the discipline and have called for a unifying framework. Now may be a suitable moment to achieve this, judging by the support being given to the systems view, enriched by dialectic and contextual postulates. Important figures in current Developmental Psychology such as Bronfenbrenner, Gottlieb, Lerner, Magnusson and Thelen have defended the idea that this perspective may become a "new theoretical framework" to guide any future investigation and interpretation concerning development (Bronfenbrenner \& Evans, 2000; Gottlieb, 1997; Lerner, 2006; Magnusson, 1998; Thelen \& Smith, 2006). Moreover, this vision appears to be coherent with the assumptions of the new "relational metatheory" proposed by Overton and Ennis (2006) to integrate traditionally opposing worldviews.

The aim of the present work is to offer an introductory and synthetic approach to prevailing theoretical assumptions

1 Endereço para correspondência: Facultad de Psicología, Departamento de Psicología Evolutiva y de la Educación, Campus Vida, 15782 Santiago de Compostela, España.E-mail: carolina.tinajero@usc.es. on Developmental Psychology. We start this article by briefly mentioning some core antecedents of the systemic view, then going on to analyze its core concepts. Basing on widely accepted recent system theories, we indicate their roots and the concrete way in which they are applied to developmental analysis today. The article closes with an analysis of general research implications and challenges of the systems view.

\section{Antecedents of the Modern Systems View}

The systemic perspective of development appeared with the convergence of theoretical formulations from different disciplines; they shared a holistic view of the objects or phenomena being dealt with. This meant affirming that they had a relationship of interdependence with their context, shaping a whole whose characteristics are not reducible to its component parts (Fogel, 1993). In Developmental Psychology, the ideas of Kurt Lewin (1890-1947) had a particular impact. According to his field theory, conduct may not be considered independently from the field, or the context within which it occurs. Individuals and their world would join together in a close relationship named life space. It was represented as an ellipse, with the physical environment on its exterior (Lewin, 1998).

In 1933 Bertalanffy published "Modern theories of development: An introduction to theoretical biology". He was presenting his system theory as an alternative to the 
mechanistic and vitalistic explanations of development. The author expressed this point as follows:

The solution to this antithesis in biology has to be sought by using an organismic or system theory of the organism which, on one hand, and as opposed to the machine theory, may discover that the essence of the organism lies in the harmony and coordination between processes, and which on the other does not interpret this co-ordination as vitalism does, using a mystical entelechy, but instead by considering the imminent strengths of the living system itself. (pp. 177-178)

The term "system" referred to totalities that would construct themselves in a continual transactional process with their surroundings. Assuming the isomorphism of the systems that had been studied by different disciplines, Bertalanffy proposed a series of general principles. They may be applied to the development of systems, regardless of the type of elements that formed them or the forces involved. These principles included two that expressly incorporated the holistic perspective. The first one of complexity, referred to the interdependence between different parts of a system and between the system as a whole and its component parts. The other one concerned with the organization of the system, different from the organization of the parts separately. A third principle would characterize this global organization as a hierarchical pattern. Finally, another two principles would bring directionality to transactions between the parts of a system. According to the principle of self-stabilization, systems include mechanisms to maintain their state or trajectory. According to the principle of equifinality, different transactions may lead to a limited number of patterns of organization (Bertalanffy, 1968).

Amongst the first applications of the systems theory in the field of Developmental Psychology, Heinz Werner's work was of particular importance. He analyzed psychological processes in the context of the global organismic system. It was assumed to be formed by different parts such as locomotion, sight, and thought. They would go through phases of imbalance that would lead to structural reorganization, leading in turn to different types of behavior (Werner, 1948). As a guiding principle, Werner took the embryogenetic principle of orthogenesis and translated it to mental development. It was defined as a trajectory from a state of relative globality and lack of differentiation, leading towards a state of increased differentiation, articulation and hierarchical integration.

From Werner up to modern times, systemic principles have been present in Developmental Psychology, and have integrated dialectic and contextualist proposals. For example, Jean Piaget (1896-1980) described development as an adaptive process in which the biological and psychological characteristics of the organism would interact with their environment. This process would facilitate the integration of the environment in the subject's knowledge structures and the transformation of these structures by the action of the environment. A dialectic balance would be established between both sub-processes, respectively named assimilation and accommodation, which would lead to types of organization of increasing complexity (Piaget, 1969).
Lev Seminovitch Vygotsky (1896-1934) was also inspired by dialectic principles. Nevertheless, his main contribution to the systemic view would be the relevance given to contextual factors in the explanation of development, both at inter-individual and sociocultural level. Vygotsky considered that the higher functions had their origins in the child's relationship with more competent children or with adults. They were then reconstructed internally; he named this process internalization. The author also pointed out that during development, subjects' thoughts are conformed according to cultural norms. On the other hand, culture itself was considered by the author a product of the contributions made by individuals throughout successive generations (Vygotsky, 1960).

Systemic, dialectic and contextualist components have impregnated the developmental formulas of the followers of Piaget, Vygotsky and other influent contemporaries, such as the ecological and life-span theories (Bronfenbrenner, 1979; Baltes, Reese, \& Lipsitt, 1980) that are still valued today. Their points of convergence with the most recent systemic theories are referred to in the following section.

\section{Basic Concepts of the Modern System View}

The core assumption of the modern system perspective is still holistic; it states that the individual "develops and functions psychologically as an integrated organism. Maturational, experiential and cultural contributions are fused in this ontogeny. Single aspects do not develop and function in isolation, and they should not be divorced from totality in analysis" (Magnusson \& Cairns, 1996, p. 12). This idea appears to have firmly taken root in Developmental Psychology, as stated by Lerner (1998): "in contemporary developmental theories, the person is not biologized, psychologized or sociologized. Rather the individual is "systemized"' (p. 1). Modern Developmental Psychology studies individuals within their context: the totality analyzed is the person-environment system (Lerner, 1998; Magnusson \& Stattin, 2006).

In line with the systemic principles of complexity and organization, the person-environment system is considered to comprise multiple and integrated levels, organized in qualitatively different ways (Gottlieb, 1991; Lerner, 1985). In accordance with the systemic principle of hierarchical pattern, each level of the system is considered simultaneously as a totality seen in relation to lower levels, and a subsystem in relation to higher levels (Magnusson \& Stattin, 1998, 2006). It is also assumed that more complex levels adopt the laws of the simpler levels of which they are formed, and add new laws of their own.

The subsystems specified and/or analyzed by different theories and investigations that fit the current system perspective form part of the organismic, psychological and environmental levels. However, they are treated with different degrees of detail, meaning we may establish a continuum that ranges from a psychobiological-developmental approach, to a developmental-contextual approach, using the terms introduced by Gottlieb (1997) and Lerner (1991) respectively. The psychobiological extreme includes approaches that differentiate sublevels within the biological level, and consider other levels in a more general fashion. 
The contextual extreme comprises approaches that analyze the environment in more detail. The former includes approaches that adopt a comparative strategy, or that focus on exchanges of material or energy between subsystems. The latter tends to concentrate on the exchange of information between individuals, and consider both social and cognitive phenomena (The Carolina Consortium of Human Development, 1996; Lerner, 1991).

For example, in the psychobiological extreme of the continuum of system approaches, we may situate the work of Greenough (1991). In an attempt to illustrate the many ways in which the organism's exterior environment may influence genetic expression, the author identifies the following biological sublevels: DNA, cell nucleus, cytoplasm, cell and organ. He details interaction processes between levels that influence the expression of genes. Among other examples, the author refers to the role of visual experience in activating the gene that codes for tubilin, an integral protein in the axons and dendrites that support the functional connections of the visual system. In more recent studies, Greenough and co-workers reviewed experience effects on brain development (see for example Dong \& Greenough, 2004; Grossman et al., 2003; Kramer et al., 2004).

Gottlieb $(1991,1997)$ distinguished the biological levels of neural activity and genetic activity, a third level of behavior and the last one formed by physical, social and cultural aspects of environment. The author aimed to demonstrate the integration of biological and social factors in the determination of inter-sensory development. He carried out an ingenious series of experiments manipulating the sensory experiences of developing birds and their capacity for neural and/or behavioral response to multi-modal information (Gottlieb, 1997; Gottlieb, Wahlsten, \& Lickliter, 2006). He also explored the interaction between a particular genotype and rearing conditions as a determining factor for certain CNS deficits or psychopathological behaviors (Gottlieb, 2007; Gottlieb \& Tucker, 2002)

The work of Magnusson concerning personality development in adolescence (Magnusson, 1998) represents a midway point in this psychobiological-contextual continuum. It includes the interdependence between hormonal, cognitive and affective function and the subject's social environment. In particular, it has revealed the importance of the role played by the adolescent's self-concept with regard to the association of early or late biological maturation during puberty with the indicators of the socialization process.

The work of Lerner and Bronfenbrenner is closer to the contextual extreme of the continuum of system approaches; they differentiate sublevels within the environmental level, while considering organismic and psychological levels with a lesser degree of detail. Lerner (Ford \& Lerner, 1992; Lerner, 1995a) described the biological, psychological, interpersonal, social, cultural, physical-ecological and historical components of the subject's changing developmental niche as necessary in defining individual development. Bronfenbrenner's ecological theory and its latest reformulation, the bioecological model, also break down the environment into different levels, namely microsystem, mesosystem, exosystem and macrosystem (Bronfenbrenner, 1995; Bronfenbrenner \& Morris, 1998; Bronfenbrenner \& Evans, 2000).
Apart from the levels described, the most consistently outstanding feature of the different systemic approaches is the interdependence between intra- and inter-level processes of change. It is assumed that changes in an element at one level may respond to others that occur in other elements from the same or other levels, which in turn may affect these and/ or other elements (Lerner, 1985; Lerner, Skinner, \& Sorell, 1980). The influence some elements may have over others may extend either to higher or lower levels, or remain at the same level (Gottlieb, 1997). The relationships that exist between elements are considered as bidirectional or reciprocal, whereby one element that affects another may be influenced by it in turn. This type of relationship has been variously referred to as transaction (Baltes \& Graf, 1997; Sameroff, 1975, 1989; Scarr, 1982), coaction (Gottlieb, 1997; Gottlieb, et al., 2006), co-construction (Baltes, Lindenberger, \& Staudinger, 2006; Kindermann \& Valsiner, 1995; Valsiner, 1996), co-genesis (Herbst, 1995; Valsiner, 1995), fusion (Lerner, 1989, 1998) or interaction (Bronfenbrenner \& Morris, 1998; Lerner, 1978, 1985; Magnusson \& Stattin, 1998). This final term frequently appears as dynamic interaction, referring to supplementary relational characteristics. Lerner $(1978,1985,1989)$ distinguishes between a conventional version of the notion of interaction that he refers to as weak or static, and another that is strong or dynamic, and illustrates the difference by referring to the triadic relationships established between the organism, environment and behavior. The conventional notion is present in explanations that impose the unidirectionality of a given relational vector. As an example, Lerner mentions the work of traditional behaviorists Bijou and Baer (1961) with regard to development. The use made by the authors of the term 'interaction' is weak, as the relationship is established between past experience (contained within the organism) and actual experience (given by the environment), which are qualitatively identical. They also reject the influence of the organism on the environment and the influence of the development produced by the interaction on the organism and the environment. Another example of the weak notion of interaction is included in Piagetian theory, which accepts the effect of the environment and individual behavior in facilitating or inhibiting development, but not that they affect the direction, sequence or quality of development. Dynamic interaction, unlike the previous versions, would mean the chance of a real change in the different related elements for all of the others (Lerner, 1985, 1989).

Magnusson and Stattin $(1998,2006)$ indicate that as well as reciprocity, dynamic interaction involves nonlinearity: the lack of obligation to suit a lineal function. This feature is considered as being a focal point of dynamic system theories, and is made operational by applying mathematical models used in thermodynamics (Fogel, King, \& Shanker, 2008; Thelen, 1989; Thelen \& Smith, 2006; Van Geert, 1994).

This relationist perspective of developmental processes just described involves a relativist interpretation of its outcomes, as these depend on the specific characteristics of the related components. For example, in the case of interactions between the organism and the environment, the implications of a particular organismic attribute for development will vary according to environmental conditions, whereby the influence of a particular type of environment will not be 
the same on different organisms (Bronfenbrenner \& Evans, 2000; Lerner, 1998, 2006). This type of reasoning is typical in contextualist perspectives, and has mainly been expressed in the importance given to the environmental aspects and transformations that these undergo as a source of intra- and inter-individual variability in development (Baltes, 1987; Kindermann \& Valsiner, 1995; Lerner et al., 1980; Reese, 1991). However, the most recent theoretical proposals have included the interest of the role played in diversity by organismic and psychological characteristics themselves, and have underlined their transitory nature (Baltes, Lindeberger, \& Staudinger, 2006; Bronfenbrenner, 1995; Lerner, 1996; Magnusson, 1998). In any case, relativism means transcending the normative development and focusing on diversity. In the words of Lerner, Fisher and Weinberg (2000) "behavioral and social scientists have shown increasing appreciation of the diversity of patterns of individual and family development that exist and comprise the range of human structural and functional characteristics" (p. 26). Also, considering that change is an intrinsic characteristic of developmental systems, the temporal dimension has become particularly important in present day developmental perspectives, as the results of development will vary according to changes in the person and environment throughout time (Bronfenbrenner \& Morris, 1998, 2006; Gottlieb, 1991, 1996; Lerner, 1996; Magnusson, 1995).

The characteristics already covered in this article (holism, multi-level analysis, relationism and relativism) lead to a dispersive perspective of development, which accepts novelty as a possibility and denies pre-determinism, or the idea that development follows an unalterable or inevitable course. Novelty in ontogeny has usually been attributed either to instructions contained in the genetic code, or to the incorporation of information from the individual's physical or social environment. In both cases, it is assumed that the emergent properties exist prior to their appearance in the developing person, and so are not really a novelty except in the individual (Dent-Read \& Zukow-Goldring, 1997; Lautrey, 1998; Thelen, 1989). Systemic theories, however, adopt the principle of self-organization in order to explain novelty. According to this principle, reorganization occurs as a response to disturbances in the different levels of the system, leading to new structural and functional forms (Fischer \& Bidell, 2006; Magnusson \& Stattin, 1998, 2006; Sameroff, 1989). This proposal is connected with the dialectic principle of transformation of quantity into quality, which establishes that when the magnitude of the phenomenon's intrinsic properties transcend certain limits, then quantitative change leads to a qualitative or structural reorganization of higher level. This leads to the appearance of a new phenomenon, controlled by a new set of laws (Hopkins \& Butterworth, 1990; Wozniak, 1975). Self-organization is central to modern theories of non-lineal dynamic systems. As Van der Maas and Hopkins (1998) stated, "what is interesting about discontinuous shift in the collective variable of a non-linear system is that it is driven by a linear change in an existing (control) parameter without the addition of a new variable" (p. 2). As the individual makes changes to the characteristics of the environment during this process, which in turn lead to disturbances in the individual, an affirmation is made of the individual's status as co-producer of their own development, and taking part in the socio-cultural change of the species (Baltes \& Graff, 1997; Lerner, 1995b; Magnusson, 1995; Sameroff, 1989).

Therefore, the current systemic view opens the way to individuality in ontogeny, a feature that is reaffirmed by the purposeful nature attributed to human conduct (Brandstädter, 2006; Lerner, 2006; Magnusson, 1998; Spencer et al., 2006; Valsiner, 2006). According to specific experiences in their environment and the needs, objectives and plans that arise in the person, development acquires a particular character. For Magnusson and Stattin (1998), this is a fundamental aspect that reveals a clear difference between the dynamic processes produced in the person-environment system and other holistic processes. We find an interesting application of the idea in the selection, optimization and compensation developmental model proposed by Baltes and Baltes (1990). The first term refers to the prioritization of developmental goals. The second term refers to the acquisition of specific goal-related skills. The third term consists of the inversion of additional resources in response to some type of decline in goal-relevant means, with the aim of maintaining the desired level of functioning. Initially applied in the explanation of adulthood and aging, the model has recently been extended to adolescence by Lerner, Freund, DeStefanis and Haberlas (2001).

Dispersiveness, however, has limits in the systems view; these are found in the internal logic of the organism (Gollin, 1981; Sameroff, 1989; Scarr, 1982) and in the regularities of the environment (Dannefer \& Perlmuter, 1990; Dowd, 1990; Gottlieb, 1997; Valsiner, 1997). Firstly, development is interpreted as the adaptation of an individual to successive organismic (maturational) and environmental changes that have their own internal organization, based around genetic and socio-cultural aspects (Baltes, 1987; Cole, 1992; Gariépy, 1995; Gottlieb, 1991; Sameroff, 1989). Secondly, in line with the systemic principle of self-stabilization, the organism is defended as tending to respond to any alterations produced by these changes with homeostatic or homerhetic processes. The former are intended to maintain states, and the latter to maintain sequences or trajectories (Sameroff, 1989; Magnusson \& Cairns, 1996; Thelen, 1989, 2005). This tendency is generally attributed to the organism's responsive capacity at any given moment - its plasticity - (Gottlieb, 1991; Gottlieb, Wahlsten, \& Kickliter, 1998) or its impermeability to changes that may lead to the breakdown or destruction of the system, referred to as allostasis (Magnusson \& Stattin, 1998). Thirdly, it is considered that the environment delimits development, an effect which Gottlieb (1991) and Valsiner (1997) compare to the organizational role played by the genes, and which Sameroff (1989; Sameroff \& Suomi, 1996) refers to as environtype and which Cole (1996) defines as prolepsis.

In a recent study, Grossman et al. (2003) integrated this dual genetic and environmental regulating action, in an attempt to explain the pathological deviations of normal psychological development. To do so, they took Waddington's metaphor of canalization and included non-genetic canalizing experiences that were absent in the original proposal. 
In Gottlieb's concept of probabilistic epigenesis (1998, 2007) we find a clear reflection of systemic dispersivity and its limits. It affirms the emergent nature of the developmental process, and rejects that this process follows an unalterable course: this is conceived as probable in relation to the normative. Magnusson and Stattin (1998) echo this idea when they affirm that the processes of psychological development "are lawful but unpredictable" (p. 687).

The impossibility of precisely predicting developmental processes is not only the result of intra- and inter-individual variability and self-organization. It is also a consequence of the acceptance of a type of causality which until recently has been lacking in explanations of development. It is referred by Lerner $(1996,1998)$ as configurational or field causality and implies that none of the levels of the person-environment system, or elements in any level, are considered to be primordial in causal terms. Magnusson and Stattin (1998) defined this idea in the following terms:

In the dynamic interaction process... what initiates a specific process and maintains it over time may vary. A psychological factor may start a biological process, which is then maintained by physiological factors... similarly, psychological factors can maintain a process that affects his or her own environment in many different ways directly and indirectly... the implication of this view is that the concepts of independent and dependent, and of predictors and criteria, lose the absolute meaning that they have in traditional research, which assumes unidirectional causality. What may function as a criterion or dependent variable at a certain stage of a process may, at the next stage, serve as a predictor or independent variable (p. 702).

Also, configurational causality is relational; Kindermann and Valsiner (1995), for example, indicate that development is not determined by either individuals or their contexts, but instead by the complex interconnections that are produced between both. They defend that developmental psychologists should concentrate on these interconnections instead of each separate element. Similarly, Gottlieb (1996) states that "the behavioral (or organic, or neural) outcomes of development are the consequence of at least (at minimum) two specific components of coaction (e.g. person-person, organism-organism, organism-environment, cell-cell, nucleus-cytoplasm, sensory stimulation-sensory system, activity-motor behavior). The cause of development - what makes development happen - is the relationship of the two components, not the components themselves." (p. 69). Recently, Gottlieb and Tucker (2002) have reaffirmed the role of this type of relational or coactive causality in the explanation of normal and abnormal development.

Finally, Gottlieb (1996) refers directly to the component of novelty that is implicit in this type of causality. According to the author, "an important feature of developmental systems is that causality is often not 'linear' or straightforward. In developmental systems, the coaction of $X$ or $Y$ often produces $W$ rather than more $X$ or $Y$, or some variant of $X$ or $Y$ ' (p. 74).

In conclusion, individual development is considered in modern systemic terms as a process in which new properties emerge as a result of dynamic interactions between the different levels of the person-environment system, and whose product is not certain but probable. More specifically, its main premises are:

1) That the object of study of Developmental Psychology is the person-environment system. As the individual develops as an integrated organism, contributions made to this process by maturation, experience or culture should not be analyzed separately.

2) The person-environment system is formed by multiple levels of organization that are qualitatively different and integrated.

3) Dynamic interactions exist between the different levels, bidirectional transactions that have the ability to modify the elements which they act upon.

4) The effect of these transactions depends on the characteristics of the elements that are interacting, and the moment when this takes place.

5) Development does not follow an unalterable course: it responds to certain laws, but is unpredictable.

\section{General Research Implications and Challenges of the Present Systems View}

The conceptual framework described in developmental research has numerous implications. Firstly, systemic relativism is concerned with the external validity of investigation, and the possibility of generalizing the results (Lerner, 1995b; 1998; Lerner et al., 1980; Magnusson \& Stattin, 1998). Consequently, investigations that focus on individual and contextual diversity are more widely accepted than those concentrating on "typical" individuals and "standard environments". Magnusson (1998, 2000; Magnusson \& Stattin, 1998, 2006) emphasizes the benefits of longitudinal and cross-cultural designs aimed at extending the margins of generalizability imposed by the age of the subjects and the context analyzed. He also refers to the benefits of research focused on the person approach, as opposed to the traditional variable approach, and which, by discovering relational forms between the subsystems of the person and/or the environment, explains inter-individual and inter-contextual diversity. Lerner (1995b; Lerner, Fisher, \& Sorell, 2000) indicates that studies that are intended to be explanatory and with "ecological" concerns, may take the shape of intervention policies and programs. As "experimental manipulations" in the "real world" they may provide data about person-context relations, and the plasticity that may be available to enhance human development.

In order to comprehend the reciprocal and dynamic nature of systemic relations, the most important factor is to adapt the investigative methods used to the characteristics of the variables being analyzed, avoiding any prejudice towards qualitative methods and to analyze both whole and molecular processes (Foster, \& Kalil, 2008; Lerner, 2006; Lerner et al. 1980; Magnusson \& Stattin, 1998).

Systemic dispersivity involves abandoning prediction as the final goal of scientific research. According to Magnusson and Stattin (1998), this should be substituted by the comprehension and explanation of the processes that drive individual functioning and development. Bronfenbrenner and Morris 
$(1998,2006)$ emphasize a type of investigation which, by adopting a discovery mode, would allow hypotheses to be created with sufficient explanatory power and precision to be able to be subjected to empirical testing. This basically consists of the "successive confrontations between theory and data leading toward the ultimate goal of being able to formulate hypotheses that both merit and are susceptible to scientific assessment in the verification mode" (Bronfenbrenner \& Morris, 2006, p. 802).

However, perhaps the most direct implication of the holistic-systemic perspective is the way in which it gives little consideration to studies analyzing isolated aspects of the person-environment system, and values multidimensional studies (Bronfenbrenner, 1995; Lerner, 1991, 1995b; 1998; Magnusson, 1995, 1998). These assessments are usually accompanied by the call for interdisciplinary collaboration in the effort to create a developmental science which, using the theoretical framework described, proposes investigations that consider the variables of the different systemic levels (Bronfenbrenner \& Evans, 2000; Cole, 1996; Lerner, 2006; Magnusson, 1995). This call for collaboration which was present in the earliest work concerning the systemic perspective, the socio-cultural and life span movements, has gone from strength to strength, and has received institutional support. In particular, this included the Nobel Symposium of 1994, which brought together specialists from the fields of medicine, biology and psychology to reflect on the possibilities of contributing from within their respective disciplines to the comprehension of human development from a holistic and interactive perspective (Diamond, 2007; Magnusson \& Cairns, 1996). We would also mention the appearance of the journal “Applied Developmental Science" edited by R.M. Lerner and C.B. Fisher, and the "Carolina Consortium on Human Development", which forms part of the Developmental Science Center at the University of North Carolina, under the auspices of R. B. Cairns, and with the participation of Elder, Gottlieb, Magnusson and Sameroff, among other scientists firmly dedicated to creating a new synthesis regarding development (Cairns, Elder, \& Costello, 1996; Gottlieb, 1991; Magnusson, 1998; The Carolina Consortium on Human Development, 1996).

On the contrary to this organizational response, the practical application in research of the methodological proposals inspired by the systemic perspective has not been as widespread as we would expect, judging by publications in Developmental Psychology journals. Some years ago, Thelen (1989) complained that any theoretical systemic considerations were usually relegated to the discussion section of articles, which paradoxically upheld the insufficiency of traditional explanations based on main and interaction effects. The author affirmed that the systemic vision included a series of major obstacles for empirical analysis, and that for this reason most investigators remained firmly attached to the "old ways". In more moderate terms, Gottlieb (1991) denounced the insensitivity of investigators concerning human diversity and contextual variation. In turn, Bronfenbrenner (1995) called for researchers to give as much consideration to personal variables as that which he had previously demanded for contextual variables. Recently, Valsiner (2006) still denounced that "most of child psychology continues to thrive on the basis of reduction of complexity to averaged data and considering these averages as established general norms" (p. 168).

The slow acceptance of the system view in empirical research may be attributed to theoretical reasons and practical ones. Firstly, its suitability to interpretations of development that were previously incompatible may be interpreted as ambiguity, particularly with regard to its dispersive nature. Taken to extremes, adopting for example a perspective that Baltes (1987) refers to as radical contextualism, and Lerner and Kaufman (1985) as pure contextualism, the dispersiveness of the model may lead to a concept of development that is quite random.

The limits suggested for dispersiveness (the internal logic of the organism and regularities of the environment) are equally ambiguous, although it would be unreasonable to expect much precision in general theories about development. However, this does mean that investigators have to make their own decisions on where the limits are in each specific developmental phenomenon under study.

As regarding to more clearly methodological concerns, the systemic model is eclectic, yet tremendously demanding. It does not reject the use of any type of design or technique, but places emphasis on the study of the different person-environment levels, and the consideration of interaction between them. This is almost certainly an impossible task in its strictest sense. Criticism resulting from this matter from Plomin, Cronbach and Gergen was contested by Magnusson and Stattin (1998), who stated that acceptance of the systemic model does not imply that the complete person-environment system has to be studied in every investigation. Instead, researchers should simply make sure that the level of complexity of the phenomenon studied is made explicit, with the plans for their work designed around a systemic analysis based on the observation of the phenomenon in a specific level. Using the systemic model also guarantees a reference to a common space for scientific concepts when interpreting the results. In the same line, Witherington and Margett (2009) argue that "any empirical investigation of development necessarily compromise the complexity of the system as a whole by analyzing only some of the myriad of relationships that go toward establishing the whole. Studies of development involve choosing a viable - and therefore limited - set of relationships in a system to study." (p. 255).

Magnusson and Stattin's (1998) and Witherington and Margett's (2009) comments take some of the pressure off of researchers faced with something as ambitious as the systemic model. However, we would also mention one final cause for concern: the emphasis that has been placed on relativism. As the model accepts any possibility in the determination of development and its products, the applicability of the results from investigations becomes increasingly less reliable, and converts the intervention into a type of experiment. Without denying the transitory nature of our knowledge and of intervention strategies based on this knowledge, the formulation of the systemic model is extreme enough to create a feeling of despondency amongst developmental psychologists interested in the applied perspective of Developmental Psychology. 
We do not consider these controversial points as limitations, but instead as challenges to be met. As Magnusson and Stattin (1998) stated, the complexity of the systemic model corresponds to the complexity of the object of study in our discipline, and this is something that should not be overlooked.

\section{References}

Baltes, P. B. (1987). Theoretical propositions of life-span developmental psychology: On the dynamics between growth and decline. Developmental Psychology, 23, 611-626.

Baltes, P. B., \& Baltes, M. M. (1990). Psychological perspectives on successful aging: The model of selective optimization with compensation. In P. B. Baltes \& M. M. Baltes (Eds.), Successful aging: Perspective from the behavioral sciences (pp. 1-34). New York: Cambridge University Press.

Baltes, P. B., \& Graf, P. (1997). Psychological aspects of aging: Facts and frontiers. In D. Magnusson (Ed.), The lifespan development of individuals: Behavioral, neurobiological, and psychological perspectives (pp. 427-460). New York: Cambridge University Press.

Baltes, P. B. Lindenberger, U., \& Staudinger, U. M. (2006). Life span theory in developmental psychology. In W. Damon \& R. M. Lerner (Eds.), Handbook of child psychology: Vol. 1. Theoretical models of human development ( $6^{\text {th }}$ ed., pp. 569664). Hoboken, NJ: John Wiley \& Sons.

Baltes, P. B., Reese, H. W., \& Lipsitt, L. P. (1980). Life-span developmental psychology. Annual Review of Psychology, $31,65-110$.

Bertalanffy, L. von (1968). General system theory. New York: Braziller.

Bertalanffy, L. von. (1962). Modern theories of development: An introduction to theoretical biology. General system theory. New York: Harper.

Bijou, S. W., \& Baer, D. M. (1961). Child development: A systematic and empirical theory. New York: AppletonCentury-Crofts.

Brandstädter, J. (2006). Action perspectives on human development. In W. Damon \& R. M. Lerner (Eds.), Handbook of child psychology: Vol. 1. Theoretical models of human development ( $6^{\text {th }}$ ed., pp. 516-568). Hoboken, NJ: John Wiley \& Sons.

Bronfenbrenner, U. (1995). The bioecological model from a life course perspective: Reflections of a participant observer. In P. Moen, G. H. Elder, \& K. Lüscher (Eds.), Examining lives in context (pp. 599-618). Washington, DC: American Psychological Association.

Bronfenbrenner, U. (1979). The ecology of human development. Cambridge, MA: Harvard University Press.

Bronfenbrenner, U., \& Evans, G.W. (2000). Developmental science in $21^{\text {st }}$ century: Emerging questions, theoretical models, research designs and empirical findings. Social Development, 9, 115-125.

Bronfenbrenner, U., \& Morris, P. A. (1998). The ecology of developmental processes. In W. Damon \& R. M. Lerner (Eds.), Handbook of child psychology: Vol. 1. Theoretical models of human development ( $5^{\text {th }}$ ed., pp. 993-1028). New York: John Wiley \& Sons.
Bronfenbrenner, U., \& Morris, P. A. (2006). The bioecological model of human development. In W. Damon \& R. M. Lerner (Eds.), Handbook of child psychology: Vol. 1. Theoretical models of human development ( $6^{\text {th }}$ ed., pp. 793-828). Hoboken, NJ: John Wiley \& Sons.

Cairns, R. B., Elder, G. H., \& Costello, E. J. (1996). Developmental science. Cambridge, MA: Cambridge University Press.

Cole, M. (1996). Cultural psychology. A one and future discipline. Cambridge, MA: Harvard University Press.

Cole, M. (1992). Culture in development. In M. H. Bornstein \& M. E Lamb (Eds.), Developmental psychology: An advanced textbook ( $3^{\text {rd }}$ ed., pp. 731-789). Hillsdale, NJ: Lawrence Erlbaum.

Dannefer, D., \& Perlmutter, M. (1990). Development as a multidimensional process: Individual and social constituents. Human Development, 33, 108-137.

Dent-Read, C., \& Zukow-Goldring, P. (1997). Introduction: Ecological realism, dynamic systems and epigenetic systems approaches to development. In C. Dent-Read \& P. ZukowGoldring (Eds.), Evolving explanations of development. Ecological approaches to organism-environment systems (pp. 1-22). Washington, DC: American Psychological Association.

Diamond, A. (2007). Interrelated and interdependent. Developmental Science, 10, 152-158.

Dong, W. K., \& Greenough, W. T. (2004). Plasticity of nonneural brain tissue: Roles in development disorders. Mental Retardation and Developmental Disabilities Research Reviews, 10, 85-90.

Dowd, J. J. (1990). Ever since Durkheim: The socialization of human development. Human Development, 33, 138-159.

Fischer, K. W., \& Bidell, T. R. (2006). Dynamic development of action and thought. In W. Damon \& R. M. Lerner (Eds.), Handbook of child psychology: Vol. 1. Theoretical models of human development ( $6^{\text {th }}$ ed., pp. 313-399). Hoboken, NJ: John Wiley \& Sons.

Fogel, A., King, B. J., \& Shanker, S. G. (2008). Human development in the twenty-first century. Cambridge: Cambridge University Press.

Fogel, A. (1993). Developing through relationships. New York: Harvester Wheatsheaf.

Ford, D. H., \& Lerner, R. M. (1992). Developmental systems theory. An integrative approach. Newbury Park, CA: Sage.

Foster, E. M., \& Kalil, A. (2008). New methods for new questions: Obstacles and Opportunities. Developmental Psychology, 44, 301-304.

Gariépy, J. L. (1995). The evolution of a developmental science: Early determinism, and a new systemic approach. Annals of Child Development, 11, 167-224.

Gollin, E. S. (1981). Developmental plasticity: Behavioral and biological aspects of variations in development. New York: Academic Press.

Gottlieb, G. (1998). Normally occurring environmental and behavioral influences on gene activity: From central dogma to probabilistic epigenesis. Psychological Review, 105, 792-802.

Gottlieb, G. (1997). Commentary. A systems view of psychobiological development. In D. Magnusson (Ed.), The lifespan development of individuals: Behavioral, neurobiological, and psychological perspectives (pp. 76-103). New York: Cambridge University Press. 
Gottlieb, G. (1996). Developmental psychobiological theory. In R. B. Cairns, G. H. Elder, \& E. J. Costelo (Eds.), Developmental science (pp. 63-77). New York: Cambridge University Press.

Gottlieb, G. (1991). Experimental canalization of behavioral development: Theory. Developmental Psychology, 27, 4-13.

Gottlieb, G. (2007). Probabilistic epigenesis. Developmental Science, 10, 1-11.

Gottlieb, G., \& Tucker, C. (2002). A relational view of causality in normal and abnormal development. Developmental Psychopathology, 14, 421-435.

Gottlieb, G., Wahlsten, D., \& Lickliter, R. (2006). The significance of biology for human development: A developmental psychobiological systems view. In W. Damon \& R. M. Lerner (Eds.), Handbook of child psychology: Vol. 1. Theoretical models of human development ( $6^{\text {th }}$ ed., pp. 210-257). Hoboken, NJ: John Wiley \& Sons.

Greenough, W. T. (1991). Experience as a component of normal development: Evolutionary considerations. Developmental Psychology, 27,14-17.

Grossman, A. W., Churchill, J. D., McKinney, B. C., Kodish, I. M. Otte, S. L., \& Greenough, W. T. (2003). Experience effects on brain development: Possible contributions to psychopathology. Journal of Child Psychology and Psychiatry, 44, 33-63.

Herbst, D. P. (1995). What happens when we make a distinction: An elementary introduction to co-genetic logic. In T. A. Kinderman \& J. Valsiner (Eds.), Development of person-context relations (pp. 67-82). Hillsdale, NJ: Lawrence Erlbaum.

Hopkins, B., \& Butterworth, G. (1990) Concepts of causality in explanations of development. In G. Butterworh \& P. Bryant (Eds.), Causes of development. Interdisciplinary perspectives (pp. 3-32). New York: Harvester Wheatsheaf.

Kindermann, T. A., \& Valsiner, J. (1995). Individual development, changing contexts, and the co-construction of person-context relations in human development. In T. A. Kindermann \& J. Valsiner (Eds.), Development of person-context relations (pp. 1-9). Hillsdale, NJ: Lawrence Erlbaum.

Kramer, A. F., Bherer, L. Colcombe, S. J., Dong, W., \& Greenough, W. T. (2004). Environmental influences on cognitive and brain plasticity during aging. Journals of Gerontology - Series A Biological and Medical Sciences, 59, 940-957.

Lautrey, J. (1998). Psicología del desarrollo y psicología diferencial: ¿hacia un cambio en el estatuto de la variabilidad? Anuario de Psicología, 29, 61-86.

Lerner, R. M. (1978). Nature, nurture, and dynamic interactionism. Human Development, 21, 1-20.

Lerner, R. M. (1985). Individual and context in developmental psychology: Conceptual and theoretical issues. In J. R. Nesselroade \& A. Von Eye (Eds.), Individual development and social change: Explanatory analysis (pp. 155-183). New York: Academic Press.

Lerner, R. M. (1989). Developmental contextualism and the lifespan view of person-context interaction. In M. H. Bornstein \& J. S. Bruner (Eds.), Interaction in human development (pp.217243). Hillsdale, NJ: Lawrence Erlbaum.

Lerner, R. M. (1991). Changing organism-context relations as the basic process of development: A developmental contextual perspective. Developmental Psychology, 27, 27-32.

Lerner, R. M. (1995a). The place of learning within the human development system: A developmental contextual perspective. Human Development, 38, 361-366.
Lerner, R. M. (1995b). Developing individuals within changing contexts: Implications of developmental contextualism for human development research, policy, and programs. In T. A. Kinderman \& J. Valsiner (Eds.), Development of personcontext relations (pp. 13-33). Hillsdale, NJ: Lawrence Erlbaum.

Lerner, R. M. (1996). Relative plasticity, integration, temporality, and diversity in human development: A developmental contextual perspective about theory, process, and method. Developmental Psychology, 32, 781-786.

Lerner, R. M. (1998). Theories of human development: Contemporary perspectives. Handbook of child psychology: Vol. 1. Theoretical models of human development $\left(5^{\text {th }}\right.$ ed., pp. 1-24). New York: John Wiley \& Sons.

Lerner, R. M. (2006). Developmental science, developmental systems, and contemporary theories of human development. In W. Damon \& R. M. Lerner (Eds.), Handbook of child psychology: Vol. 1. Theoretical models of human development ( $6^{\text {th }}$ ed., pp. 1-17). Hoboken, NJ: John Wiley \& Sons.

Lerner, R. M., Fisher, C. B., \& Weinberg, R. A. (2000). Applying developmental science in the 21 st century: International scholarship for our times. International Journal of Behavioral Development, 24, 24-29.

Lerner, R. M., Freund, A. M., De Stefanis, I., \& Habermas, T. (2001). Understanding developmental regulation in adolescence: The use of the selection, optimization, and compensation model. Human Development, 44, 29-50.

Lerner, R. M., \& Kauffman, M. B. (1985). The concept of development in contextualism. Developmental Review, 5, 309-333.

Lerner, R. M., Skinner, E. A., \& Sorell, G. T. (1980). Methodological implications of contextal/dialectic theories of development. Human Development, 23, 225-235.

Lewin, M. A. (1998). Kurt Lewin: His psychology and a daughter's recollections. In G. A. Kimble, C. A. Boneau, \& M. Wertheimer (Eds.), Portraits of pioneers of psychology (Vol. 3, pp. 105120). Washington: American Psychological Association/ Lawrence Erlbaum.

Magnusson, D. (1995). Individual development: A holistic, integrated model. In P. Moen, G. H. Elder, \& K. Lüscher (Eds.), Examining lives in context. Perspective on the ecology of human development (pp. 19-60). Washington, DC: American Psychological Association.

Magnusson, D. (1998). The person in developmental research. In J. G. Adair, D. Bélanger, \& K. L. Dion (Eds.), Advances in psychological science: Vol. 1. Social, personal and cultural aspects (pp. 495-511). London: Taylor \& Francis.

Magnusson, D. (2000). The individual as the organizing principle in psychological inquiry: A holistic approach. In L. R. Bergman, L. G. Nilson, \& L. Nystedt (Eds.), Developmental Science and the holistic approach (pp. 33-47). Mahwah, NJ: Erlbaum.

Magnusson, D., \& Cairns, R. B. (1996). Developmental science: Toward a unified framework. In R. B. Cairns, H. Elder, \& E. J. Costello (Eds.), Developmental science (pp. 7-30). New York: Cambridge University Press.

Magnusson, D., \& Stattin, H. (1998). Person-context interaction theories. In W. Damon \& R. M. Lerner (Eds.), Handbook of child psychology: Vol. 1. Theoretical models of human development ( $5^{\text {th }}$ ed., pp. 685-759). New York: John Wiley \& Sons. 
Magnusson, D., \& Stattin, H. (2006). The person in context: a holistic-interactionistic approach. In W. Damon \& R. M. Lerner (Eds.), Handbook of child psychology: Vol. 1. Theoretical models of human development ( $6^{\text {th }}$ ed., pp. 400-465). Hoboken, NJ: John Wiley \& Sons.

Overton, W. F., \& Ennis, M. D. (2006). Cognitive-developmental and behavior-analytic theories: Evolving to complementarity. Human Development, 49, 143-172.

Piaget, J. (1969). Psychologie et Pédagogie. Paris: Denoël.

Reese, H. W. (1991). Contextualism and development psychology. In H.W. Reese (Ed.), Advances in child development and behavior (Vol. 2, pp. 187-230). New York: Academic Press.

Sameroff, A. J. (1989). Commentary: General systems and the regulation of development. In M. R. Gunar \& E. Thelen (Eds.), The Minnesota Symposia on Child Psychology: Vol. 22. Systems and development (pp. 219-235). Hillsdale, NJ: Lawrence Erlbaum.

Sameroff, A. (1975). Transactional models in early social relations. Human Development, 18, 65-79.

Sameroff, A., \& Suomi, S. J. (1996). Primates and persons: A comparative developmental understanding of social organization. In R. B. Cairns, G. H. Elder, \& E. J. Costello (Eds.), Developmental science (pp. 97- 120). Cambridge, MA: Cambridge University Press.

Scarr, S. (1982). Development is internally guided, not determined. Contemporary Psychology, 27, 852-853.

Spencer, J. P., Clearfield, M., Corbetta, D., Ulrich, B., Buchanan, P., \& Schöner, G. (2006). Moving toward a grand theory of development: In memory of Esther Thelen. Child Development, 77, 152-1538.

The Carolina Consortium of Human Development (1996). Developmental science: Toward a unified framework. In R. B. Cairns, G. H. Elder, \& E. J. Costello (Eds.), Developmental Science (pp.7-30). Cambridge, MA: Cambridge University Press.

Thelen, E. (1989). Self-organization in developmental processes: Can systems approaches work? In M. Gunnar \& E. Thellen (Eds.), The Minnesota Symposia on Child Psychology: Vol. 22. Systems and development (pp. 77-117). Hilldale, NJ: Lawrence Erlbaum.

Thelen, E. (2005). Dynamic systems theory and the complexity of change. Psychoanalytic Dialogues, 15, 255-283.

Thelen, E., \& Smith, L. B. (2006). Dynamic systems theories. In W. Damon \& R. M. Lerner (Eds.), Handbook of child psychology: Vol. 1. Theoretical models of human development $\left(6^{\text {th }}\right.$ ed., $\mathrm{pp}$. 258-312). Hoboken, NJ: John Wiley \& Sons.
Valsiner, J. (1995). Processes of development, and search for their logic: An introduction to Herbst's co-genetic logic. In T. A. Kinderman \& J. Valsiner (Eds.), Development of person-context relations (pp. 55-66). Hillsdale, NJ: Lawrence Erlbaum.

Valsiner, J. (1996). Co-constructionism and development: A sociohistoric tradition. Anuario de Psicología, 69, 63-82.

Valsiner, J. (1997). Constructing the personal through the cultural: Redundant organization of psychological development. In E. Amsel \& K. A. Renninger (Eds.), Change and development. Issues of theory, method, and application (pp. 27-42). Mahwah, NJ: Lawrence Erlbaum.

Valsiner, J. (2006). Developmental epistemology and implications for methodology. In W. Damon \& R. M. Lerner (Eds.), Handbook of child psychology: Vol. 1. Theoretical models of human development ( $6^{\text {th }}$ ed., pp. 166-209). Hoboken, NJ: John Wiley \& Sons.

Van der Maas, H. L. J., \& Hopkins, B. (1998). Developmental transitions: So what's new? British Journal of Developmental Psychology, 16, 1-13.

Van Geert, P. (1994). Dynamic systems of development. Change between complexity and chaos. New York: Harvester Wheatsheaf.

Vygotsky, L. S. (1960). Razvitie vysshikh psikhicheskikh funktsii [Development of the higher mental functions]. Moscow: APN.

Werner, H. (1948). Comparative psychology of mental development. Chicago: Follett.

Witherington, D. C., \& Margett, T. E. (2009). Systems and dynamic systems: The search for inclusive merger. Human Development, 52, 251-256.

Wozniak, R. H. (1975). A dialectical paradigm for psychological research: Implications drawn from the history of psychology in the Soviet Union. Human Development, 18, 18-34. 